\title{
Availability of risky geoengineering can make an ambitious climate mitigation agreement more likely
}

\author{
Adrien Fabre ${ }^{1,2} \&$ Gernot Wagner (10 ${ }^{3,4 凶}$
}

Some countries prefer high to low mitigation $(H>L)$. Some prefer low to high $(L>H)$. That fundamental disagreement is at the heart of the seeming intractability of negotiating a climate mitigation agreement. Modelling global climate negotiations as a weakest-link game brings this to the fore: Unless everyone prefers $H$ to $L$, $L$ wins. Enter geoengineering $(G)$. Its risky and imperfect nature makes it arguably inferior to any country's preferred mitigation outcome. However, absent a global high-mitigation agreement, countries facing disastrous climate damages might indeed wish to undertake it, effectively ranking $\mathrm{H}>\mathrm{G}>\mathrm{L}$. Meanwhile, those least affected by climate damages and, thus, least inclined to agree to an ambitious mitigation agreement, might be unwilling to engage in risky geoengineering, resulting in $L>$ $H>G$. With these rankings, all players prefer $H$ to $G$, and the mere availability of a credible geoengineering threat might help induce an ambitious climate mitigation agreement $(H)$. The analysis here introduces the simplest possible model of global climate negotiations and derives the conditions for this outcome. These conditions may indeed be likely, as long as geoengineering is viewed as a credible albeit risky emergency response given the danger of low mitigation levels.

\footnotetext{
${ }^{1}$ Paris School of Economics, Paris, France. ${ }^{2}$ Université Paris 1 Panthéon-Sorbonne, Paris, France. ${ }^{3}$ New York University Department of Environmental Studies, New York, NY, USA. ${ }^{4}$ NYU Wagner School of Public Service, New York, NY, USA. ${ }^{\circledR}$ email: gwagner@nyu.edu
} 


\section{Introduction}

ame theory helps frame the strategic interactions among countries (Schelling, 1960), with global climate negotiations as a prominent example (Barrett, 2007, 2003, 1994; MacKay et al., 2015). That holds for multilateral negotiations under the umbrella of the United Nations Framework Convention on Climate Change as well as for bilateral negotiations and those among smaller groups of countries. Science points to the need for ambitious climate action (IPCC, 2018). Many countries are indeed pursuing ambitious action on their own (Aklin and Mildenberger, 2018), only in part for strategic reasons (Kotchen, 2018; Nordhaus, 2020, 2015). ${ }^{1}$ Meanwhile, assuming symmetric players in a weakest-link game (Sandler, 1997, chap. 2), as long as one country, or group of countries, prefers high mitigation to low $(\mathrm{H}>\mathrm{L})$, while the other prefers $\mathrm{L}>\mathrm{H}$, an ambitious negotiated agreement $(\mathrm{H})$ is unlikely. We here introduce what we consider to be the simplest possible game-theoretic framework that demonstrates this lack of an ambitious negotiated climate agreement. Doing so allows us to communicate and synthesize results of previously published research on climate negotiations and geoengineering (G) (e.g., Millard-Ball, 2012; Moreno-Cruz, 2015; Sandler, 2018; Urpelainen, 2012).

\section{Simple game theory explains lack of ambitious climate agreement}

Consider two countries or groups of countries, 1 and 2. Both countries would have to prefer $\mathrm{H}$ to $\mathrm{L}$ for $\mathrm{H}$ to prevail (Table 1) (Nash, 1951). This holds as long as the aggregate level of mitigation is characterized by the minimum of each country's mitigation policy, a stylized representation of the arithmetic of climate negotiations focused on strategic interaction among symmetric players (MacKay et al., 2015).

This weakest-link negotiation game might be the simplest representation of the lack of collective action. It stands in contrast to models of total mitigation as the sum of each country's contribution (Barrett, 2007; Sandler, 2018), though aggregating mitigation efforts, too, can lead to a weakest-link game under some reasonable conditions. If the combination of diverging mitigation efforts $\left(\left(\mathrm{L}_{1}, \mathrm{H}_{2}\right)\right.$ or $\left.\left(\mathrm{H}_{1}, \mathrm{~L}_{2}\right)\right)$ led to moderate overall mitigation effort $\mathrm{M}$, it might be reasonable to treat $\mathrm{M}$ and $\mathrm{L}$ the same for purposes of this analysis. That might hold especially if there is a threshold of sorts between $\mathrm{M}$ and $\mathrm{H}$. If so, only the outcome $\mathrm{H}$ might lead to stabilizing global climates, while both $\mathrm{L}$ and $\mathrm{M}$ would imply indefinite warming, albeit at different speeds.

Our framework also assumes that mitigation is costly, with $\mathrm{H}$ costlier than L. Mitigation might not be as costly as often assumed (Gillingham and Stock, 2018), leading, for example, to some countries pursuing ambitious climate action on their own (Wagner et al., 2015), or it might be in some countries' selfinterest to pursue more ambitious mitigation policies to coax others into doing the same (Kotchen, 2018; Nordhaus, $2020,2015)$. Nordhaus $(2020,2015)$, in particular, points to how powerful countries taking ambitious climate mitigation action could force others into following suit. Either possibility may indeed help break through the global climate negotiations logjam (Barrett, 2007). Failing that, Table 1 presents the simplest possible

\begin{tabular}{|c|c|c|}
\hline Moves by players 1 and 2 & $\mathbf{H}_{2}$ & $\mathbf{L}_{2}$ \\
\hline $\mathrm{H}_{1}$ & $\mathrm{H}$ & L \\
\hline $\mathrm{L}_{1}$ & $\mathrm{~L}$ & $\mathrm{~L}$ \\
\hline
\end{tabular}

explanation for the woeful lack of ambitious climate action to date. Any player would only play $\mathrm{H}$, if $\mathrm{H}$ is also the preferred outcome of the other player(s). Otherwise the one player choosing $\mathrm{H}$ would incur the extra mitigation cost in vain. This is often described as the "free-rider" problem, the direct result of climate mitigation's public goods nature (Baumol, 1952).

Geoengineering is cheap and imperfect, and all-too tempting Geoengineering $(\mathrm{G})$ introduces an entirely new set of challenges into global climate policy negotiations. Some have focused on G crowding out ambitious mitigation, necessitating complex governance regimes (Quaas et al., 2017; Weitzman, 2015). This often comes under the heading of "moral hazard" (Keith, 2000; Lin, 2013; Wagner and Zizzamia, 2020). The mere availability of G might also do the opposite, encouraging more mitigation action (Merk et al., 2016). In strategic climate negotiations, the threat of risky $\mathrm{G}$ by players suffering most from $\mathrm{L}$ has indeed been shown to have the potential to lead to H (Millard-Ball, 2012; MorenoCruz, 2015; Urpelainen, 2012).

In contrast to mitigation, geoengineering $(G)$ is often characterized as fast, cheap, and imperfect (Keith, 2000; Mahajan et al., 2018). Here we drop "fast" and focus on the latter two. In fact, while $G$ is often synonymous with solar radiation management or modification (SRM), with carbon dioxide removal (CDR) instead best thought as expensive mitigation (Moreno-Cruz et al., 2018), here some CDR techniques could count, too. For example, ocean fertilization in an attempt to remove carbon from the atmosphere might be "slow" yet is also both cheap and imperfect. The combination makes it risky, widening the list of possible $G$ techniques relevant to this analysis.

Modelling $G$ necessitates extending our game to two periods: first, players choose mitigation levels $\mathrm{H}$ or L; second, they decide on $\mathrm{G}$. The latter could be a decision on degree: how much $\mathrm{G}$ to pursue. For simplicity, we assume it is a zero-one decision: whether to pursue $G$ or not. Indeed, G is so cheap (Smith and Wagner, 2018) that the largest hurdle is the willingness to engage in it in the first place. $^{2} \mathrm{G}$ is also so powerful that one country's choice determines the overall outcome. While for mitigation, the ambition of the global agreement here equals the minimum level of ambition across the two players, for $\mathrm{G}$ it only takes one player to pursue it for the entire world to experience the outcome-both its potential (net) benefits, and the potentially large risks. Moreover, we assume that the aggregate level of mitigation is irrelevant to a geoengineered climate, so that the climate resulting from the players' moves across both periods can be characterized by $\mathrm{H}, \mathrm{L}$, or G. Conversely, the preferences of each player can be reduced to their rankings over possible resulting climates $\mathrm{H}, \mathrm{L}$, or $\mathrm{G}$.

Table 2 summarizes the impact of $\mathrm{G}$ on the negotiated outcome: As in Table 1, $\mathrm{H}$ only happens if both players prefer it. Meanwhile, either player resorting to $G$ implies the entire world facing its consequences. These properties not least explain G's "free-driver" effect (Barrett, 2008; Schelling, 1996; Victor et al., 2009; Wagner and Weitzman, 2012; Weitzman, 2015). G is at once so cheap and powerful that a single player's preferences

Table 2 Climate policy resulting from each pair of moves. Low mitigation (L) without geoengineering (G) dominates high mitigation (H) (Table 1), while $\mathbf{G}$ dominates all.

\begin{tabular}{llll} 
Moves by players $\mathbf{1}$ and $\mathbf{2}$ & $\mathbf{H}_{\mathbf{2}}$ & $\mathbf{L}_{\mathbf{2}}$ & $\mathbf{G}_{\mathbf{2}}$ \\
\hline $\mathrm{H}_{1}$ & $\mathrm{H}$ & $\mathrm{L}$ & $\mathrm{G}$ \\
$\mathrm{L}_{1}$ & $\mathrm{~L}$ & $\mathrm{~L}$ & $\mathrm{G}$ \\
$\mathrm{G}_{1}$ & $\mathrm{G}$ & $\mathrm{G}$ & $\mathrm{G}$ \\
\hline
\end{tabular}


Table 3 Climatic policy outcomes depending on each player's full set of preferences. Availability of geoengineering (G) could lead to high mitigation agreement $(H$, in bold roman). Symmetric outcomes are omitted for simplicity.

\begin{tabular}{|c|c|c|c|c|c|c|}
\hline 1 and 2 & $\mathbf{H}>\mathbf{L}>\mathbf{G}$ & $\mathbf{H}>\mathbf{G}>\mathbf{L}$ & $\mathbf{L}>\mathbf{G}>\mathbf{H}$ & $\mathbf{L}>\mathbf{H}>\mathbf{G}$ & $\mathbf{G}>\mathbf{L}>\mathbf{H}$ & $\mathbf{G}>\mathbf{H}>\mathbf{L}$ \\
\hline $\mathrm{H}>\mathrm{L}>\mathrm{G}$ & $H$ & & & & & \\
\hline$H>G>L$ & H & $\boldsymbol{H}$ & & & & \\
\hline$L>G>H$ & $\mathrm{~L}$ & G & $L$ & & & \\
\hline $\mathrm{G}>\mathrm{L}>\mathrm{H}$ & G & G & G & G & G & \\
\hline $\mathrm{G}>\mathrm{H}>\mathrm{L}$ & G & G & G & G & G & G \\
\hline
\end{tabular}

dominate the outcome, regardless of how many other players there are.

\section{Simple game theory of how availability of $\mathbf{G}$ can induce $\mathbf{H}$}

If all players agreed on either of the three possible negotiation positions as their top choice, the outcome would be just that, shown in bold italics in Table 3. If any player preferred $G$ to all other choices, $G$ would win (shown in italics). That leaves four cases.

In all four, one player ranks $\mathrm{L}$ as the top choice, while the other prefers $\mathrm{H}$ above all else. That situation mimics the "simple" negotiation, shown in Table 1, save for the addition of G. If G were ranked last by both, the game would collapse to the simple negotiation, where one ranks $\mathrm{L}>\mathrm{H}$ and the other ranks $\mathrm{H}>\mathrm{L}$. G does not interfere. $\mathrm{L}$ wins. Conversely, if $\mathrm{G}$ were to be ranked second by both players, $G$ would win. Two cases remain.

If the player who prefers $\mathrm{L}$ ranked $\mathrm{G}>\mathrm{H}$ while the other player who prefers $H$ ranked $L>G, L$ would win. $G$ does not alter the outcome, as both players prefer L to G. That, however, would imply that those most hurt by climate change, and thus most interested in pursuing $\mathrm{H}$, would rank $\mathrm{L}>\mathrm{G}$. That might be a justifiable ranking, given G's inherent risks. But desperation can beget risky choices.

Here this willingness on the part of those preferring $\mathrm{H}>\mathrm{L}$ to engage in risky choices to avoid the worst implies that those same players might also rank $G>L$. G is not the first choice, but it might be better than $\mathrm{L}: \mathrm{H}>\mathrm{G}>\mathrm{L}$. The fundamental assumption here-and this is indeed an assumption-is that, among those most vulnerable to a low mitigation climate, expensive and safe $\mathrm{H}$ is still preferred to cheap yet risky G. (If that were not the case, and $\mathrm{G}>\mathrm{H}, \mathrm{G}$ would win.) Conversely, those ranking $\mathrm{L}>\mathrm{H}$ reveal themselves to be relatively less affected by climate damages and, thus, less inclined to agree to an ambitious mitigation agreement. At the same time, the perceived possibility of a disastrous impact of $\mathrm{G}$ implies that they might be less willing to engage in risky geoengineering, resulting in $\mathrm{L}>\mathrm{H}>\mathrm{G}$.

These rankings, in turn, immediately lead to the final case, with $\mathrm{H}$ (in bold in Table 3) as the outcome, induced by the availability of $\mathrm{G}$. It is also the only situation with $\mathrm{H}$ as the outcome despite only one player, or group of players, ranking $\mathrm{H}$ first. The threat of G leads both players to rank $\mathrm{H}>\mathrm{G}$, although one player would still prefer $\mathrm{L}>\mathrm{H}$.

\section{Discussion}

We are far from the first to analyse the impact of the mere availability of $\mathrm{G}$ on mitigation outcomes (e.g., Keith, 2000; Merk et al., 2016; Quaas et al., 2017; Sandler, 2018; Wagner and Zizzamia, 2020; Weitzman, 2015). Others have indeed argued how the threat of G, coupled with G's inherent uncertainties, can lead to more ambitious mitigation action within and across countries (Heyen, 2015; Millard-Ball, 2012; Moreno-Cruz, 2015; Urpelainen, 2012; Victor et al., 2009). ${ }^{3}$ Here we boil this reasoning down to its bare essentials, focusing on simple, relative preference ordering of each player over climate outcomes H, L, and G. These players could be singular actors in bilateral negotiations. They could also stand in for groups of players. G's fundamental characteristics might lead players previously stuck in a lowmitigation equilibrium $\mathrm{L}$ to consider $\mathrm{H}$.

For $\mathrm{G}$ to induce $\mathrm{H}$, the threat of deploying $\mathrm{G}$ must be credible. And it must indeed be a threat-something opting for $\mathrm{H}$ can avoid. All that relies on $G$ being risky and shrouded in uncertainty. The more research discovers about $G$, decreasing its potential risks and uncertainties for everyone, the less it might be able to induce $\mathrm{H}$. Indeed, a new discovery might affect the players' expected payoffs, making $G$ the worst policy outcome in case of bad news, or the preferred one in case of good news. Conversely, the possibility of $\mathrm{G}$ deployed as a supplement to $\mathrm{H}$ might have similar effects of helping to induce $\mathrm{H}$, but it may well be too tempting to trade off some mitigation action for moderate geoengineering (Moreno-Cruz et al., 2018).

Lastly, if any player-a singular state, for example, tempted by $G$ to maintain the high-emitting status quo-were to prefer $G$ altogether, the free-driver effect kicks in and G prevails. The only possible solution in such a scenario to prevent the free driver from forcing $G$ upon everyone else: strong governance at the global level, effectively leading to a ban on unilateral G.

The mere availability of $G$, of course, is no guarantee of inducing $\mathrm{H}$. Viewed in the right light, and with the bare minimum of oft-invoked assumptions, it might help break the decades-long logjam of climate negotiations-both formally at the international level, and informally among smaller groups of state and possibly non-state actors (Reynolds and Wagner, 2019).

\section{Methods}

The solution relies on a subgame-perfect Nash equilibrium among players in a non-cooperative game (Nash, 1951; Selten, 1965).

Received: 9 December 2019; Accepted: 20 April 2020;

Published online: 17 June 2020

\section{Notes}

1 In fact, there is good reason to believe why it is domestic politics, in particular domestic political capture, that is the largest stumbling block for ambitious climate action, rather than international politics (Mildenberger, 2020; Seto et al., 2016).

2 While not unusual to assume as much, at least in discussing SRM technologies such as stratospheric aerosols, it does preclude using moderate $\mathrm{G}$ as part of an overall climate policy portfolio (Moreno-Cruz et al., 2018).

3 The possibility of "counter-geoengineering," too, might play this role of helping catalyse H (Bas and Mahajan, 2020; Heyen et al., 2019).

\section{References}

Aklin M, Mildenberger M (2018) Prisoners of the wrong dilemma: why distributive conflict, not collective action, characterizes the politics of climate change. https://ssrn.com/abstract=3281045. Accessed 26 May 2020 
Barrett S (2008) The incredible economics of geoengineering. Environ Resour Econ 39:45-54. https://doi.org/10.1007/s10640-007-9174-8

Barrett S (2007) Why cooperate?: the incentive to supply global public goods. Oxford University Press on Demand

Barrett S (2003) Environment and statecraft: the strategy of environmental treatymaking: the strategy of environmental treaty-making. Oxford University Press, Oxford

Barrett S (1994) Self-enforcing International Environmental Agreements. Oxf Economic Pap 46:878-894

Bas M, Mahajan A (2020) Security implications of geoengineering and countergeoengineering. Clim Change

Baumol WJ (1952) Welfare economics and the theory of the state. Harvard University Press

Gillingham K, Stock JH (2018) The cost of reducing greenhouse gas emissions. J Econ Perspect 32:53-72. https://doi.org/10.1257/jep.32.4.53

Heyen D (2015) Five essays in the economics of climate engineering, research, and regulation under uncertainty. Ruprecht-Karls-Universität, Heidelberg

Heyen D, Horton J, Moreno-Cruz J (2019) Strategic implications of countergeoengineering: clash or cooperation? J Environ Econ Manag 95:153-177

IPCC (2018) Global warming of $1.5^{\circ} \mathrm{C}$. IPCC

Keith D (2000) Geoengineering the climate: history and prospect. Annu Rev Energy Environ 25:245-284

Kotchen MJ (2018) Which social cost of carbon? A theoretical perspective. J Assoc Environ Resour Econ 5:673-694

Lin A (2013) Does geoengineering present a moral hazard? Ecol Law Q 40:673-712

MacKay DJC, Cramton P, Ockenfels A, Stoft S (2015) Price carbon-I will if you will. Nat News 526:315. https://doi.org/10.1038/526315a

Mahajan A, Tingley D, Wagner G (2018) Fast, cheap, and imperfect? US public opinion about solar geoengineering. Environ Politics 1-21. https://doi.org/ 10.1080/09644016.2018.1479101

Merk C, Pönitzsch G, Rehdanz K (2016) Knowledge about aerosol injection does not reduce individual mitigation efforts. Environ Res Lett 11:054009. https:// doi.org/10.1088/1748-9326/11/5/054009

Mildenberger M (2020). Carbon captured. MIT Press

Millard-Ball A (2012) The Tuvalu Syndrome: can geoengineering solve climate's collective action problem? Clim Change 110:1047-1066. https://doi.org/ 10.1007/s10584-011-0102-0

Moreno-Cruz JB (2015) Mitigation and the geoengineering threat. Resour Energy Econ 41:248-263. https://doi.org/10.1016/j.reseneeco.2015.06.001

Moreno-Cruz JB, Wagner G, Keith DW (2018) An economic anatomy of optimal climate policy. HKS Faculty Research Working Paper Series RWP17-028

Nash J (1951) Non-cooperative games. Ann Math 54:286-295. https://doi.org/ $10.2307 / 1969529$

Nordhaus W (2020) The climate club. Foreign Affairs

Nordhaus WD (2015) Climate clubs: overcoming free-riding in International Climate Policy. Am Econ Rev 105:1339-1370. https://doi.org/10.1257/ aer.15000001

Quaas MF, Quaas J, Rickels W, Boucher O (2017) Are there reasons against openended research into solar radiation management? A model of intergenerational decision-making under uncertainty. J Environ Econ Manag 84:1-17. https://doi.org/10.1016/j.jeem.2017.02.002

Reynolds JL, Wagner G (2019) Highly decentralized solar geoengineering. Environ Politics 1-17. https://doi.org/10.1080/09644016.2019.1648169

Sandler T (2018) Collective action and geoengineering. Rev Int Organ 13:105-125

Sandler T (1997) Global challenges: an approach to environmental, political, and economic problems. Cambridge University Press

Schelling TC (1996) Global decisions for the very long term: intergenerational and international discounting. In: Zeckhauser R, Keeney RL, Sebenius JK (eds) Wise choices: decisions, games and negotiations. Harvard Business Press, pp 152-166

Schelling TC (1960) The strategy of conflict. Harvard University Press, Cambridge
Selten R (1965) Spieltheoretische Behandlung eines Oligopolmodells mit Nachfrageträgheit: Teil i: Bestimmung des dynamischen Preisgleichgewichts. Z Gesamte Staatswiss/J Inst Theor Econ H.2: pp. 301-324

Seto KC, Davis SJ, Mitchell RB, Stokes EC, Unruh G, Ürge-Vorsatz D (2016) Carbon lock-in: types, causes, and policy implications. Annu Rev Environ Resour 41:425-452. https://doi.org/10.1146/annurev-environ-110615-085934

Smith W, Wagner G (2018) Stratospheric aerosol injection tactics and costs in the first 15 years of deployment. Environ Res Lett 13:124001. https://doi.org/ $10.1088 / 1748-9326 /$ aae $98 \mathrm{~d}$

Urpelainen J (2012) Geoengineering and global warming: a strategic perspective. Int Environ Agreem 12:375-389. https://doi.org/10.1007/s10784-012-9167-0

Victor DG, Morgan MG, Apt J, Steinbruner J, Ricke K (2009) The geoengineering option. Foreign Aff. 88: pp. 64-76

Wagner G, Kåberger T, Olai S, Oppenheimer M, Rittenhouse K, Sterner T (2015) Energy policy: push renewables to spur carbon pricing. Nat News 525:27. https://doi.org/10.1038/525027a

Wagner G, Weitzman ML (2012) Playing god. Foreign Policy

Wagner G, Zizzamia D (2020) Green moral hazards. NYU Wagner Research Paper

Weitzman ML (2015) A voting architecture for the governance of free-driver externalities, with application to geoengineering. Scand J Econ 117:1049-1068. https://doi.org/10.1111/sjoe.12120

\section{Acknowledgements}

We thank Dan Bodansky, Ritwick Ghosh, Cameron Hepburn, Daniel Heyen, Pete Irvine, Jennifer Jacquet, David Kanter, Matthew Kotchen, Juan Moreno-Cruz, Jesse Reynolds, David Victor, and Tyler Volk for discussion and feedback. All remaining errors are our own.

\section{Author contributions}

A.F. and G.W. contributed equally to conceptualizing and conducting the analysis and to writing the manuscript.

\section{Competing interests}

The authors declare no competing interests. A.F. conducted this research while visiting G.W. at NYU Wagner School of Public Service as a visiting scholar.

\section{Additional information}

Correspondence and requests for materials should be addressed to G.W.

Reprints and permission information is available at http://www.nature.com/reprints

Publisher's note Springer Nature remains neutral with regard to jurisdictional claims in published maps and institutional affiliations.

(c) (i) Open Access This article is licensed under a Creative Commons Attribution 4.0 International License, which permits use, sharing, adaptation, distribution and reproduction in any medium or format, as long as you give appropriate credit to the original author(s) and the source, provide a link to the Creative Commons license, and indicate if changes were made. The images or other third party material in this article are included in the article's Creative Commons license, unless indicated otherwise in a credit line to the material. If material is not included in the article's Creative Commons license and your intended use is not permitted by statutory regulation or exceeds the permitted use, you will need to obtain permission directly from the copyright holder. To view a copy of this license, visit http://creativecommons.org/ licenses/by/4.0/

(C) The Author(s) 2020 